\title{
SELECTION OF Beauveria bassiana AND Metarhizium anisopliae ISOLATES FOR THE CONTROL OF Blissus antillus (Hemiptera: Lygaeidae)
}

\author{
Richard Ian Samuels*; Déborah Lucienne Araújo Coracini \\ UENF-CCTA-LPP, Av. Alberto Lamego 2000 - Campos dos Goytacazes, RJ - 28013-600 - Brasil. \\ *Corresponding author <richard@uenf.br>
}

\begin{abstract}
Chinch bugs of the genus Blissus (Hemiptera: Lygaeidae) are serious pests of maize, wheat, sorghum and various grasses. This study is the first to screen isolates of Beauveria bassiana and Metarhizium anisopliae against $4^{\text {th }}$ instar and adult Blissus antillus aiming to develop a biological control program for this important pasture pest. Ten fungal isolates were initially screened and three isolates were chosen for further investigation. To determine virulence, insects were inoculated by immersion in concentrations of $5 \times 10^{8}$ conidia $\mathrm{mL}^{-1}$. Mortality was evaluated for 10 days. B. bassiana ARSEF 792 was the most virulent isolate to both nymphs and adults, causing 53 and $78 \%$ infection, respectively, and values for $\mathrm{LT}_{50}$ of 7.8 and 5.0 days, respectively. Germination studies were carried out to confirm viability and determine speed of germination as a pathogenicity factor. The production of conidia on the cadavers of insects infected with the three selected isolates was determined. The production of conidia on rice media was also evaluated. B. bassiana CG 24 produced the highest number of conidia on insects cadavers $\left(14.9 \times 10^{7}\right.$ conidia per insect $)$ and also on rice media $\left(10.6 \times 10^{9}\right.$ conidia per $\left.\mathrm{g}\right)$.
\end{abstract}

Key words: Brachiaria, chinch bug, entomopathogenic fungus, biological control

\section{SELEÇÃO DE ISOLADOS DE Beauveria Bassiana E Metarhizium Anisopliae PARA O CONTROLE DE Blissus Antillus}

\begin{abstract}
RESUMO: Percevejos do gênero Blissus (Hemiptera: Lygeidae) são pragas importantes das plantações de milho, trigo e sorgo e de vários tipos de gramíneos forrageiros. Esse estudo é o primeiro a amostrar isolados de Beauveria bassiana e Metarhizium anisopliae contra aos $4^{0}$ instares e adultos de Blissus antillus com a finalidade de desenvolver um programa de controle biológico dessa importante praga de pastagens. Dez isolados foram inicialmente testados e três foram escolhidos para maiores investigações. Para determinar a virulência, os insetos foram inoculados por imersão em suspensões de conídios a uma concentração de $5 \times$ $10^{8}$ conídios $\mathrm{mL}^{-1}$. Mortalidade foi avaliada por 10 dias. B. bassiana ARSEF 792 foi o isolado mais virulento para as ninfas e os adultos, causando 53 e $78 \%$ infecção, respectivamente, com valores de $\mathrm{TL}_{50}$ de 7,8 e 5,0 dias, respectivamente. Estudos de germinação foram feitos para confirmar a viabilidade dos isolados e determinar qual isolado germinou mais rápido, um fator de patogenicidade importante. A produção de conídios nos cadáveres dos adultos foi avaliado para os três isolados. A produção de conídios em meio de arroz também foi avaliada. B. bassiana isolado CG 24 produziu o maior número de conídios nos cadáveres $(14,9$ $\times 10^{7}$ conídios por inseto) e também em arroz $\left(10,6 \times 10^{9}\right.$ conídios por $\left.\mathrm{g}\right)$.

Palavras-chave: Brachiaria, percevejo-das-gramíneas, fungos entomopatogênicos, controle biológico
\end{abstract}

\section{INTRODUCTION}

Chinch bugs of the genus Blissus (Hemiptera: Lygaeidae) are serious pests of maize, wheat, sorghum and various grasses in the USA (Spike et al., 1994). In Brazil, a chinch bug recently identified as Blissus antillus (Leonard), causes serious damage to pastures planted with Brachiaria arrecta (T. Dur and Schinz) (tanner grass) and tangola grass (hybrid of B. arrecta and Brachiaria angola), in the states of Minas Gerais, Mato Grosso do Sul and Rio de Janeiro (Valério et al., 2000). To date, the only control method available for these insects is the application of insecticides. However, the use of insecticides on pasturelands presents restrictions, such as the need for removal of grazing cattle during chemical applications and observing a latency period, when the pasture cannot be used.

Biological control of chinch bugs using entomopathogenic fungi may provide an alternative to chemical agents. The possibility of using entomopathogenic fungi against chinch bugs is supported by reports of naturally-occurring epizootics caused by $B$. bassiana in populations of B. leucopterus (Ramoska, 1984), and by the fact that these insects were found to be highly susceptible to fungal infections under laboratory conditions (Krueger et al., 1991). 
Fungi are capable of infecting all phases of the insect's life cycle and a previous study has shown that eggs of $B$. antillus are highly susceptible to isolates of Metarhizium anisopliae (Metsch.) Sorok (Samuels et al., 2002). This work investigates for the first time the pathogenicity and virulence of isolates of $B$. bassiana and $M$. anisopliae to nymphs and adults of $B$. antillus, with the aim of developing a biological control strategy for this pest.

\section{METERIAL AND METHODS}

Blissus antillus (adults and nymphs) were collected in pastures of tanner grass (B. arrecta) in the State of Rio de Janeiro, Brazil and maintained in the laboratory under controlled conditions $(25 \mathrm{o} \mathrm{C}, 70 \pm 10 \% \mathrm{RH}$ and 14L:10D). Insects were fed on tanner grass plantlets grown from cuttings of plants collected in the field onto which the adult females laid their eggs. Grass stems were changed every two days and at that time, the eggs were carefully collected using a fine brush. Eggs were maintained in Petri dishes with damp cotton wool to avoid desiccation. On hatching (approx. 15 days), $1^{\text {st }}$ instar insects were transferred to plastic pots with tanner grass stems. When insects reached the $3^{\text {rd }}$ instar they were transferred to glass jars with plantlets of $B$. arrecta, where they were maintained until adult. Two-day-old $4^{\text {th }}$ instar and 3-5day-old adult female $B$. antillus were used in the experiments described below.

Isolates of $M$. anisopliae and B. bassiana were obtained from the collection at CENARGEN-EMBRAPA in Brasília, ESALQ in Piracicaba (São Paulo), USDAARS in Ithaca NY, or the Laboratory of Plant Protection (LPP-UENF) in Campos, Rio de Janeiro (Table 1). Fungi were grown on Sabouraud dextrose agar (dextrose $10 \mathrm{~g}$; peptone $2.5 \mathrm{~g}$; yeast extract $2.5 \mathrm{~g}$; agar $20 \mathrm{~g}$; $1 \mathrm{~L} \mathrm{H}_{2} 0$ ) at $27^{\circ} \mathrm{C}$ for 15 days. Fungal suspensions were prepared by scrapping conidia from the surface of 15 day-old cultures using a sterile loop and added to Tween 80 (0.5\% in ster- ile distilled water). Conidial concentration was determined using a Neubauer chamber. The viability of all isolates was confirmed before use in experiments using standard techniques (Goettel \& Inglis, 1997) and was at all times greater than $90 \%$.

Insects $\left(4^{\text {th }}\right.$ instar insects and adult females) were inoculated with fungal suspensions at a concentration of $5 \times 10^{8}$ conidia $\mathrm{mL}^{-1}$. Ten fungal isolates were screened for pathogenicity but only three isolates where selected for more detailed study: B. bassiana ARSEF 792; $B$. bassiana CG 24; $M$. anisopliae ESALQ 818 . Thirty nymphs or 30 adults were chosen and anaesthetised using a stream of $\mathrm{CO}_{2}$ for $5 \mathrm{sec}$, and groups of five individuals were then placed in a glass funnel lined with Whatman \#1 filter paper and inoculated with $1 \mathrm{~mL}$ of the fungal suspension. Insects were then transferred to small plastic pots lined with damp filter paper and containing tanner grass stems. Pots were maintained at $>90 \%$ plus relative humidity for $48 \mathrm{~h}$ in an incubator at $25^{\circ} \mathrm{C}$ and 14L:10D photoperiod. Control treatments received $0.5 \%$ Tween $80^{6}$. After $48 \mathrm{~h}$, treated insects were transferred to pots maintained at $70 \pm 10 \% \mathrm{RH}$; plant stems were changed every 2 days. Insect mortality was monitored daily and dead insects were surface sterilized (1 min in $92 \%$ ethanol followed by 2 rinses in sterile distilled water) and then transferred to Petri dishes lined with damp filter paper. Petri dishes containing the dead insects were maintained in a humidity chamber at room temperature ( $\left.>90 \% \mathrm{RH} ; 25^{\circ} \mathrm{C}\right)$. Insects were confirmed to have been infected by the entomopathogenic fungi only following verification of conidiogenesis. All experiments were repeated three times and Abbot's formula (Abbot, 1925) was applied to the results for mortality (control mortality was always less than $10 \%$ ). Results for percentage mortality were transformed using arcsine-squareroot to normalise distributions. Results were analysed using Analysis of Variance followed by Tukey's test. LT $_{50}$ was calculated using Probit Analysis (SPSS 10).

Table 1 - Details of the isolates of entomopathogenic fungi used in tests for pathogenicity and virulence against Blissus antillus.

\begin{tabular}{|c|c|c|c|}
\hline Accession Number & Species & Original Host & Geographical Origin \\
\hline CG04 & B. bassiana & Deois flavopicta Stal. (Homóptera: Cercopidae) & Brasília, Brazil \\
\hline CG11 & " & Sternechus subsignatus Boeh. (Coleóptera: Curculionidae) & Londrina, Brazil \\
\hline CG24 & $"$ & Euschistus heros Fabr. (Heteroptera: Pentatomidae) & Londrina, Brazil \\
\hline LPP1 & $"$ & Coleoptera (adult) & Campos, Brazil \\
\hline ARSEF 792 & $"$ & Blissus leucopterus Say (Heteroptera: Lygaeidae) & Kansas, USA \\
\hline ARSEF 2430 & $"$ & Blissus leucopterus Say (Heteroptera: Lygaeidae) & Kansas, USA \\
\hline CG144 & M. anisopliae & Piezodorus guildinii Westwood (Heteroptera: Pentatomidae) & Goiânia, Brazil \\
\hline CG46 & " & Deois incompleta Walker (Homóptera: Cercopidae) & Espírito Santo, Brazil \\
\hline ESALQ 818 & $"$ & Isolated from soil & Piracicaba, Brazil \\
\hline ESALQ 865 & $"$ & Homoptera & Goiânia, Brazil \\
\hline
\end{tabular}

Sci. Agric. (Piracicaba, Braz.), v.61, n.3, p.271-275, May/June 2004 
The rate of germination of the three most virulent isolates selected from the preliminary study was determined. Small, plastic Petri dishes $(6 \mathrm{~cm} \times 1.5 \mathrm{~cm})$ with SDA were inoculated with fungal suspensions $\left(5 \times 10^{6}\right.$ conidia $\mathrm{mL}^{-1}$ in $0.5 \%$ Tween 80$)$. The cultures were maintained at $27^{\circ} \mathrm{C}$ in the dark and germination was evaluated every $2 \mathrm{~h}$ for a total period of $24 \mathrm{~h}$. The Petri dishes were removed from the incubator to observe germination by placing the Petri dishes directly under an optical microscope. Following evaluation the dishes were returned to the incubator. One hundred conidia were counted in each field of view and three fields of view were chosen from each Petri dish (three Petri dishes per treatment). The criteria for conidial germination was the presence of a germ tube which was equal or greater in size than the conidia itself. The experiment was repeated five times to enable calculating of mean and standard deviation. The results were analysed using Analysis of Variance followed by Tukey's test $(P=0.05)$.

Differences in the production of conidia on the insect cuticle were evaluated 20 days following initial exposure of adult females to three selected fungal isolates. Five insects infected by each isolate were evaluated individually by immersion in $1 \mathrm{~mL}$ of Tween 80 $(0.5 \%)$ in a $1.5 \mathrm{~mL}$ Eppendorf tube. The tube was then vortex mixed and the resulting suspension evaluated for conidial concentration using a Neubauer chamber. The experiment was repeated three times.

The production of conidia on rice media was determined 15 days after fungal inoculation of flasks $(250 \mathrm{~mL})$ containing $25 \mathrm{~g}$ of sterilized rice, as described by Alves (1998); three flasks were used per isolate. Fungal suspensions, $1.25 \mathrm{~mL}$ of $5 \times 10^{6}$ conidia $\mathrm{mL}^{-1}$ in
$0.5 \%$ Tween 80 , were added to each flask, and flasks were incubated at $27^{\circ} \mathrm{C}$ in the dark. One gram of rice was sampled from each flask. Three flasks were sampled three times for each isolate. Tween $80(5 \mathrm{~mL}$ of $0.5 \%)$ was added to each $1 \mathrm{-g}$ rice sample in a test tube, which was subsequently vortex mixed for $1 \mathrm{~min}$. Concentration of conidia in the suspensions was determined as previously described.

\section{RESULTS AND DISCUSSION}

Only three of ten isolates tested were considered to be virulent ( $>40 \%$ adult mortality) (Table 2 ). These three isolates were selected for further screening of the pathogenicity to $4^{\text {th }}$ instar and adult insects, and studies on production of conidia.

B. bassiana ARSEF 792 was the most virulent of the three isolates, causing $53.3 \%$ mortality of nymphs (Table 2). B. bassiana ARSEF 792, was originally obtained from naturally infected B. leucopterus, and has been previously used for laboratory bioassays (Ramoska, 1984; Ramoska \& Todd, 1985). The second most virulent isolate was $M$. anisopliae ESALQ 818, which caused $35.5 \%$ mortality. Differences were observed in the rate of mortality caused by all three isolates $(P<$ $0.05)$. However, another naturally pathogenic isolate of B. bassiana from B. leucopterus, ARSEF 2430, was considered to be of low virulence to $B$. antillus (Table 2). B. bassiana ARSEF 792 was again the most virulent isolate against adult female chinch bugs, causing higher mortality than the two other isolates $(P<0.05)$. In these experiments, there was no difference between CG 24 and ESALQ 818, when mortality caused by fungal infection was compared $(P<0.05)$. A large range of con-

Table 2 - Mean percentage confirmed mortality and values for $\mathrm{TL}_{50}$ of $4^{\text {th }}$ instar and adult female Blissus antillus inoculated by immersion in conidial suspensions $\left(5 \times 10^{8}\right.$ conidia $\left.\mathrm{mL}^{-1}\right)$, assessed ten days following inoculation.

\begin{tabular}{lcccc}
\hline Fungal isolate & $\begin{array}{c}\text { Nymphal mortality } \\
(\% \pm \mathrm{SD})\end{array}$ & $\begin{array}{c}\mathrm{TL}^{50} \text { nymphs } \\
(\text { days } \text { CL })\end{array}$ & $\begin{array}{c}\text { Adult Mortality } \\
(\% \pm \text { SD })\end{array}$ & $\begin{array}{c}\mathrm{TL}^{50} \text { adults } \\
(\mathrm{days} \text { CL })\end{array}$ \\
\hline B. bassiana CG24 & $12.2 \pm 1.9 \mathrm{aB}$ & $26.3(18.2-63)$ & $44.2 \pm 5.2 \mathrm{aA}$ & $9.8(8.9-10.8)$ \\
M. anisopliae ESALQ818 & $35.5 \pm 3.8 \mathrm{bA}$ & $11.6(8.7-28)$ & $47.5 \pm 10 \mathrm{aA}$ & $9.4(8.3-11.2)$ \\
B. bassiana ARSEF792 & $53.3 \pm 6.7 \mathrm{cB}$ & $7.8(6.6-9.6)$ & $78.3 \pm 5.2 \mathrm{bA}$ & $5.0(4.2-5.8)$ \\
B. bassiana CG04 & - & - & $24.7 \pm 8.2$ & - \\
B. bassiana CG11 & - & - & $29.5 \pm 5.9$ & - \\
B. bassiana LPP1 & - & - & $35.5 \pm 2.3$ & - \\
B. bassiana ARSEF 2430 & - & - & $36.0 \pm 3.11$ & - \\
M. anisopliae CG144 & - & - & $24.3 \pm 7.3$ & - \\
M. anisopliae CG46 & - & - & $33.5 \pm 8.7$ & - \\
M. anisopliae ESALQ 865 & - & - & - \\
\hline V. & - & & - \\
\hline
\end{tabular}

Values followed by the same small letter within the same column were not different using Tukey's test $(P<0.05 \%)$. Values followed by the same capital letter were not different when comparing mortality between nymphs and adults infected with the same isolate. The results were the mean of three repetitions for each isolate. Thirty $4^{\text {th }}$ instar nymphs and adults were used for each treatment/ repetition. Results for mortality were calculated using Abbots formula. $\mathrm{TL}_{50}$ was calculated using Probit analysis. $\mathrm{CL}=$ upper and lower confidence limits. - data not obtained 
firmed mortality was also seen when screening the red mite Oligonychus yothersi (Acari: Tetranychidae) against different isolates of B. bassiana (Oliveira et al., 2002)

Results herein shown for mortality are difficult to compare with those of previous studies on Blissus because of differences in infection techniques. In previous studies, insects were infected by direct contact with dry spores for long periods of time (Ramoska, 1984; Kruger et al., 1991). Using direct contact, Ramoska (1984) achieved $100 \%$ infection of $B$. leucopterus at a concentration of $4.4 \times 10^{6}$ viable conidia per insect.

\section{Germination studies}

Germination was first observed between 6 and $8 \mathrm{~h}$ following inoculation of media. The highest percentage of germinating conidia at this time was seen in cultures of ESALQ 818 (Table 3). Conidia of $B$. bassiana ARSEF 792 and CG24 were slower to initiate germination. However, at $14 \mathrm{~h}, 90 \%$ of the conidia had germinated in cultures of all three isolates.

The rate of germination is an important factor in the infection process, with faster germinating conidia generally considered to have a greater chance of causing infection. However, germination rates on the cuticle may not reflect those seen on artificial media because of the presence of anti-fungal compounds associated with the cuticle (Charnley, 1989). In this work, the most virulent isolate, B. bassiana ARSEF 792, was not in fact the fastest to germinate.

The production of secondary inoculum on infected insects is considered to be important in the spread of infection throughout a population (Carruthers \& Soper, 1987). Conidial production on cadavers of infected, adult female insects was quantified for the three isolates (Table
$4)$, and there were differences among the three isolates $(F=10.80 ; d f=2,12 ; P<0.05)$. B. bassiana CG 24 produced the highest number of conidia, $14.88 \times 10^{7}$ conidia per insect. The same isolate $(\mathrm{CG} 24)$ produced $7.71 \times 10^{7}$ conidia per insect when infecting Triatoma infestans at $20^{\circ} \mathrm{C}$ (Luz et al., 1999).

Because the production of microbial insecticides based on entomopathogenic fungi in Brazil is routinely carried out using solid substrates such as rice, the production of conidia of the three isolates on this substrate was evaluated. Conidial production on rice grains differed among isolates $(F=59.68 ; d f=2,6 ; P<0.0001)$. $B$. bassiana CG 24 produced the highest number of conidia, $106.5 \times 10^{8}$ conidia $\mathrm{g}^{-1}$ (Table 4 ). This result was different $(P<0.05)$ from the production of conidia by B. bassiana ARSEF 792 and M. anisopliae ESALQ 818.

The lower production of conidia on rice by $B$. bassiana ARSEF 792 indicates the need for further studies to optimise conditions for sporulation of this isolate if it is to be further developed as a microbial control agent. Influence of environmental factors on the virulence and viability of the three candidate isolates is under evaluation.

\section{ACKNOWLEDGEMENTS}

To Ederaldo Azevedo da Silva and Arli de Fátima de Nogueira da Silva for technical assistance. We also thank Jacquelyn L. Blackmer for revising the manuscript, Richard Humber (USDA), Myrian Tigano (CENARGEN) and Sérgio Batista Alves (ESALQ) for supplying fungal isolates. This work was funded by grants from CAPES/ British Council (094/99; 881/13), FAPERJ (E-26/171.062/ 96) and FENORTE.

Table 3 - Conidia germination rate $(\% \pm \mathrm{SD})$ for Beauveria bassiana and Metarhizium anisopliae isolates on artificial. media

\begin{tabular}{|c|c|c|c|c|c|c|c|}
\hline Time (h) & 6 & 8 & 10 & 12 & 14 & 16 & 18 \\
\hline Isolate & & $-\cdots--1$ & - & -- \% Germin & on - & & - \\
\hline ARSEF 792 & 0 & $4.2 \pm 1.1 b^{*}$ & $38.0 \pm 7.2 b$ & $58.6 \pm 4.2 b$ & $89.2 \pm 3.0 \mathrm{a}$ & $98.4 \pm 1.1 \mathrm{a}$ & $99.2 \pm 1.1 \mathrm{a}$ \\
\hline CG 24 & 0 & $2.0 \pm 1.0 \mathrm{~b}$ & $29.8 \pm 4.7 b$ & $69.4 \pm 5.9 b$ & $95.4 \pm 2.1 \mathrm{a}$ & $99.4 \pm 0.5 \mathrm{a}$ & $99.8 \pm 0.5 \mathrm{a}$ \\
\hline ESALQ818 & 0 & $75.8 \pm 16.7 \mathrm{a}$ & $84.6 \pm 13.0 \mathrm{a}$ & $92.2 \pm 4.0 \mathrm{a}$ & $95.6 \pm 1.7 \mathrm{a}$ & $99.8 \pm 0.4 \mathrm{a}$ & $99.8 \pm 0.4 \mathrm{a}$ \\
\hline
\end{tabular}

*Mean followed by same letter within the same column were not different using Tukey's test $(P<0.05)$. The results represent the mean of five repetitions (100 conidia were counted per repetition).

Table 4 - Conidial production on the body surface of Blissus antillus adults and on rice media by isolates of Beauveria bassiana and Metarhizium anisopliae.

\begin{tabular}{lcc}
\hline Isolate & $\begin{array}{c}\text { Production of conidia per insect } \\
(\text { mean } \pm \text { SD }) *\end{array}$ & $\begin{array}{c}\text { Production of conidia per } \mathrm{g} \text { rice }\left(\times 10^{7}\right) \\
(\mathrm{mean} \pm \mathrm{SD})\end{array}$ \\
\hline B. bassiana CG24 & $14.9 \pm 3.5 \mathrm{a}$ & $106.5 \pm 6.8 \mathrm{a}^{*}$ \\
B. bassiana ARSEF792 & $9.3 \pm 2.6 \mathrm{~b}$ & $18.4 \pm 18.4 \mathrm{c}$ \\
M. anisopliae ESALQ818 & $6.7 \pm 2.2 \mathrm{~b}$ & $53.1 \pm 15.2 \mathrm{~b}$ \\
\hline
\end{tabular}

*Values followed by different letters in the same column were different $(P<0.05)$ using Tukey's Test. The data represent the means of five repetitions. 


\section{REFERENCES}

ABBOT, W.S. A method for computing the effectivness of an insecticide. Journal of Economic Entomology, v.18, p.265-267, 1925.

ALVES, S.B; PEREIRA, R.M. Produção de fungos entomopatogênicos in Alves, S.B.(Ed) Controle Microbiano de Insetos. Piracicaba: FEALQ, 1988. cap.27, p.845-867.

CARRUTHERS, R.I.; SOPER. R.S. Fungal diseases. In: FUXA, J.R.; TANADA, Y. (Ed.) Epizootiology of insect diseases. New York: John Wiley and Sons, 1987. cap.3, p.357-417.

CHARNLEY, A.K. Mechanisms of fungal pathogenesis in insects. In: WHIPPS, J.M; LUMSDEN, R.D. (Ed.) Biotechnology for improving plant growth. Cambridge: Cambridge University Press, 1989. cap.5, p.85-125.

GOETTEL, M.S.; INGLIS, D. Fungi: Hyphomycetes. In: LACEY, L. (Ed.) Manual of techniques in insect pathology. San Diego: Academic Press, 1997. cap.V-3, p.213-249.

KRUEGER, S.R.; NECHOLS, J.R.; RAMOSKA, W.A. Infection of chinch bug, Blissus leucopterous leucopterous (Hemiptera: Lygaeidae), adults from Beauveria bassiana (Deuteromycotina: Hyphomycetes) conidia in soil under controlled temperature and moisture conditions. Journal of Invertebrate Pathology, v.58, p.19-26, 1991.

LUZ, C.; SILVA, I.G.; CORDEIRO, C.M.T.; TIGANO, M.S. Sporulation of Beauveria bassiana on cadavers of Triatoma infestans after infection at different temperatures and doses of inoculum. Journal of Invertebrate Pathology, v.73, p.223-225, 1999.

OLIVEIRA, R.C.; ALVES, L.F.A.; NEVES, P.M.O.J. Suscetibilidade de Oligonychus yothersi (Acari: Tetranychidae) ao fungo Beauveria bassiana. Scientia Agricola, v.59, p.187-189, 2002. http:// www.scielo.br/scielo.php? script=sci_issuetoc\&pid=0103$901620020001 \& \operatorname{lng}=$ pt\&nrm=isso. Acesso em: 15 dez. 2003
RAMOSKA, W.A. The influence of relative humidity on Beauveria bassiana infectivity and replication in the chinch bug, Blissus leucopterous. Journal of Invertebrate Pathology, v.43, p.389-394, 1984

RAMOSKA, W.A.; TODD, T. Variation in efficacy and viability of Beauveria bassiana in the chinch bug (Hemiptera: Lygaeidae) as a result of feeding activity on selected host plants. Environmental Entomology, v.14, p.146-148, 1985.

SAMUELS, R.I.; CORACINI, D.L.A.; MARTINS DOS SANTOS, C.A.; GAVA. C.A.T. Infection of Blissus antillus (Hemiptera: Lygaeidae) eggs by the entomopathogenic fungi Metarhizium anisopliae and Beauveria bassiana. Biological Control, v.23, p.269-273, 2002.

SPIKE, B.P.; WILDE, G.E.; MIZE, T.W.; WRIGHT, R.J.; DANIELSON, S.D. Bibliography of the chinch bug, Blissus leucopterus leucopterus (Say) (Hemiptera: Lygaeidae) since 1888. Journal of the Kansas Entomological Society, v.67, p.116-125, 1994.

VALÉRIO, J.R.; REIS, P.R.; LIMA, J.O.G. Percevejo-das-gramíneas, Blissus ? leucopterus (Heteroptera: Blissidae). In: VILELA, E.F.; ZUCCHI, R.A.; CANTOR, F. (Ed.) Histórico e impacto das pragas introduzidas no Brasil. Ribeirão Preto: Holos Editora Ltda, 2000. cap.15, p.123-127.

Received May 15, 2003

Accepted March 05, 2004 